\title{
Impact of blue space in architecture and possibilities of using
}

\author{
Katarína Č́kyová, , Zuzana Vranayová \\ Faculty of Civil Engineering, Technical University of Košice, Košice, Slovakia
}

\begin{abstract}
Trends in contemporary architecture are design environmentally, economically and socially sustainable buildings. When possible, where space permits, buildings are designed in harmony and contact with nature, water. Human's relationship to water and nature in the course of history changed. Water has a very special quality as an element in landscape design. Over many centuries and in many countries it has in turn been acknowledged and exploited, and it has inspired. It has been a great provider not only in physical terms, but also in the many ways it has contributed to both natural and man-made environments through its aesthetic qualities. The presented paper shows the possibilities of using blue spaces in the urban environment but also in the indoor environment. It has been shown that these elements have a high impact on the quality of the environment, but also contribute to reducing the air temperature and thermal islands in cities. The presence of natural elements in an artificial environment is an important aspect of life quality and well-being. Use of water elements bring the opportunity how put piece of nature into the urban environment, but also inside the buildings.
\end{abstract}

\section{Introduction}

Human life and the urban environment have been indirectly linked to water and water features. Water feature, either directly or symbolically, it has been part of every Chinese gardens. In Europe, during the Renaissance, the water was introduced to garden in extremely impressive form. It was not just an aesthetic element. Water helped meet below and higher the needs of people, provided them food, protection, energy, transport, relaxation, beauty, harmony and inspiration. Human's relationship to water and nature in the course of history changed. Changes in water regimes and the associated changes in landforms, vegetation and wildlife can have significant effects on many different types of human perceptions and values [1].

In the late eighteenth century James Watt repaired a model of a Newcomen steam engine. He`s improved steam engine was turning point in history. It became the seminal of the Industry Revolution. The industrial Revolution was akin to the Agricultural Revolution of about 5000 years ago, when societies in ancient Egypt, Mesopotamia, the Indus Valley, and northern China separately began mastering the hydraulic arts of controlling water from rivers for mass-scale irrigation, and in so doing unlocked the economic and political means

\footnotetext{
*Corresponding author: katarina.cakyova@tuke.sk
} 
for advanced civilization to begin. Watt steam engines abetted the rise of urban metropolises and improved the health and longevity of the residents, by pumping up freshwater from rivers for drinking, cooking, sanitation, and even firefighting. The sanitary revolution helped foment transformations in human health, demography, and clean drinking water that sustained massive modern industrial urban concentrations [2][3].

Gradually with the urban sprawl and urbanistic transformation the nature and the direct contact with nature more or less disappearing from cities. Water was to "hide" in the pipeline of construction, sewage. Forest embodied in several trees. Solitaire in the middle of an artificial environment asphalt and concrete. According to the World Urbanization Prospects released by the United Nations in 2014, more than half $(54 \%)$ of the world's population lives in urban areas and the number is expected to increase, reaching 66 per cent by 2050 (United Nations 2014). The rapid urbanization process changes the type of land use radically, which increases the number of motors, high-rise buildings and artificial heat sources.

\section{Water in the artificial environment}

"It can be an ocean, a big lake, a small lake, river, stream, or pond; it might be placid or fast-moving, tranquil or falling, with trees reflected or with rapids. Water is a highly priced element in the landscape," Kaplan [4].

Water has a very special quality as an element in landscape design. Over many centuries and in many countries it has in turn been acknowledged and exploited, and it has inspired. It has been a great provider not only in physical terms, but also in the many ways it has contributed to both natural and man-made environments through its aesthetic qualities [5]. Viewing water in the landscape has been found to have beneficial psychophysiological effects, potentially serving important restorative health needs [6]. In urban area, we can find water features not only in the natural form (lake, river) but in the artificial form, such as fountain and elements (fig.1), too. These elements are often complemented by works of art.

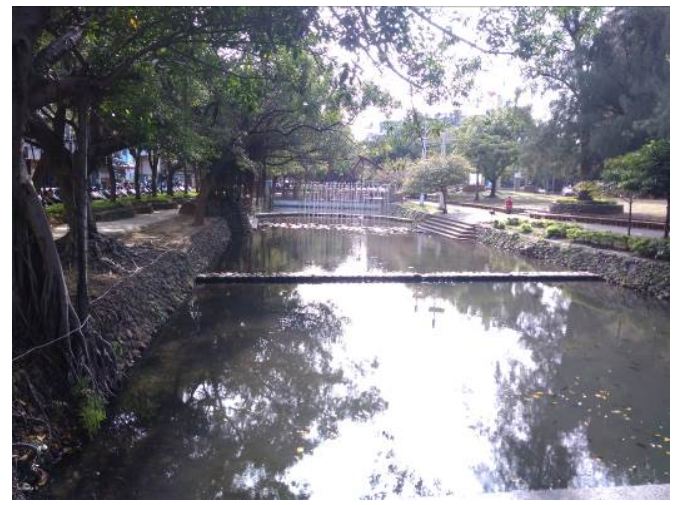

Fig. 1. Waterway in city center, Hsinchu, Taiwan

\subsection{Evaporative cooling by blue spaces}

Climate change is regarded as one of the greatest challenges to cities in the future. Some proposals focus on incorporating urban green space to counter the rise in temperature and ensuing public health hazards. Urban blue spaces, defined as all surface waters within a city, are regarded as a possible factor for temperature mitigation [7]. In urban areas, blue spaces have a positive effect upon microclimate of the surroundings with the relative 
cooling impact it has on evaporative procedure. Hence, evaporative cooling might be one of the pretty efficient methods of passive cooling for urban spaces and buildings. A water body temperature is capable of being lower than the surrounding urban environment around 2- $6^{\circ} \mathrm{C}$. According to these findings; one may conclude that the rise of evapotranspiration in cities, that has roots in vegetation and water body, can efficiently mitigate the influence of the urban heat island [8].

\subsection{Taiwan and water}

Taiwan, officially the Republic of China (ROC), is a state in East Asia. The CIA World Factbook reports that over $93 \%$ of Taiwanese are adherents of a combination of the polytheistic Chinese popular religion, Buddhism, Confucianism, and Taoism [9].This fact is also reflected in architecture and connection to nature.

Water carries important metaphors about the energies of life. It is hidden depths are a source of wisdom, so staring into it provides opportunities for contemplating the deeper meaning of life. Traditionally, people believed that water had sacred power and that it flowed from the very source of spiritual life, over time it has retained a nurturing and healthy energy. Water stimulates and refreshes chi energy. Introducing a water feature is the ideal way to enhance the energy of career area. Because of its life-giving qualities, water is strongly associated with money so a water features or a thirsty plant that needs regular watering placed in any wealth area will boost finances and luck.

Of the five energies, tree energy is boosted by water so the two areas of the bagua associated with it, Elders and Fortunate Blessings, would also benefit from water if you wanted to enhance those aspects of life [10].

In the Taoist literature, water is a very commonly used metaphor for one's "path in life". Water, in flowing downhill, adapts to the turns and twists and declivities it encounters, often taking odd paths or being momentarily interrupted, but always proceeding. The Tao te ching contains two explicit and important mentions of water, the first in verse:

The best way to live is to be like water. For water benefits all things and goes against none of them. It provides for all people and even cleanses those places a man is loath to go. In this way it is just like the Tao [11].

\section{Water and the built environment, Taiwan}

Presented three examples of buildings in Taiwan show the interconnection of architecture and the nature, mainly water, as has been shown by the strong roots in the culture of this country. From this reason the water does not appear only in the religion buildings but also in the commercial buildings in the middle of the city. Water spaces are part of almost every city or building in this country.

\subsection{Water-Moon Monastery by Kris Yao, Taipei, Taiwan}

"This monastery shall be 'Flower in space and Moon in water'." --- Master Shenyen

The earliest roots of Buddhism can be traced back to India from where it gained a devoted following throughout Asia. With over half a billion followers Buddhism is one of the world's major religions. The largest populations of Buddhist followers are in Asian countries including Taiwan where over one-third of the population is Buddhist. Dharma Drum Mountain (DDM) is an international Buddhist organization based in Taiwan. DDM was founded in 1989 by Chinese Buddhist Monk Sheng Yen as a merging of Chung-Hwa 
Institute of Buddhist Culture (founded in 1956) and Nung Chan (founded by Sheng Yen in 1975, also a Buddhist organization).

Water Moon Monastery was completed in 2012, and designed by the famous Taiwanese architect Kris Yao. When asked of what his vision for the future temple would be, Master Sheng Yen, the founder of the Monastery and Dharma Drum Buddhist Group, answered that he "sees" the temple in his meditation dhyana, "It is a Flower in Space, Moon in Water," he said. "Let's name it the Water-Moon Monastery". Thus began the Water-Moon Monastery. Situated on the vast Guandu plain, facing the Keelung River and with the Datun Mountain as its backdrop, the design takes advantage of its natural surroundings and strives to build a tranquil spiritual place [12].

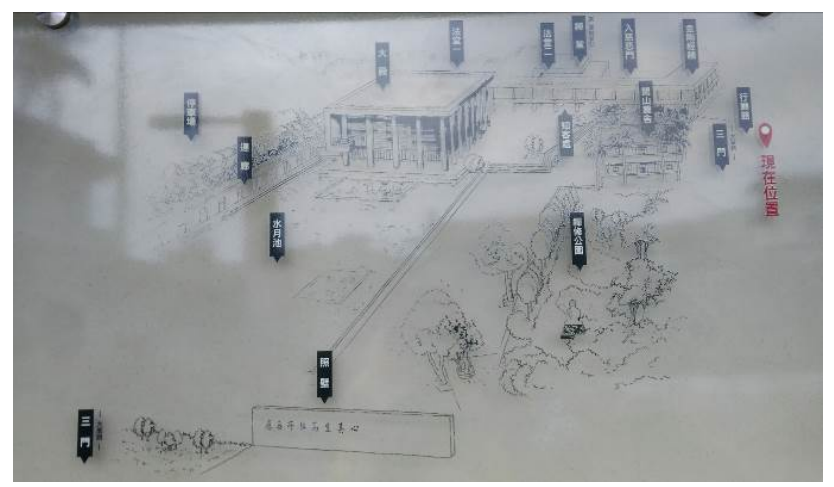

Fig. 2. Plan of Water-Moon Monastery, Taipei, Taiwan

After passing through two walls of different heights that serve as buffer from the expressway outside, upon entering the temple, visitors face the view of the Main Hall that sits at the far end of an 80-meter long lotus pond (fig.3). The reflections on the pond of the over-sized colonnades and the flowing golden drapes in between create a scene of illusory quality. Using architectural concrete as the main material, the design reduces the colour and form to a minimum, conveying the spirit of Zen Buddhism. The design intend to be simple and minimal which enhance the natural beauty of the existing landscape and connect back to the architecture to create a spiritual retreat for users and visitors. Essence of the watermoon concept: on a clear night, the moon will reflect in the clear water of the lotus pond, this reflect mind seem as big and bright as the moon itself, but in the end it is only an illusion, like most other things on earth.

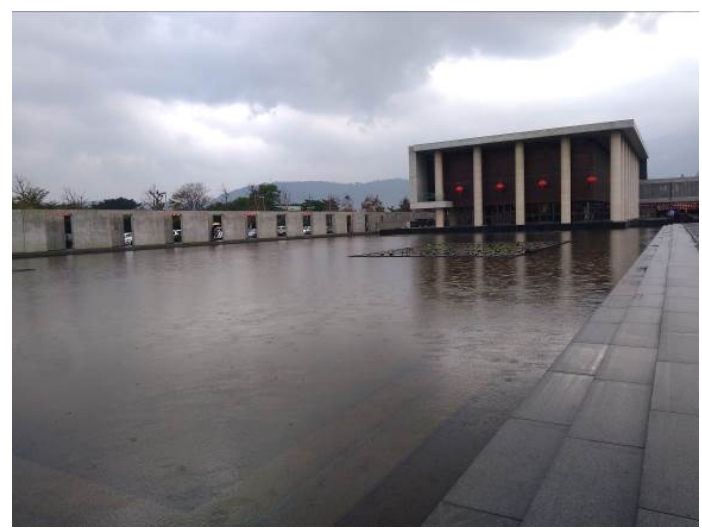

Fig. 3. Main Hall and lotus pond, Water-Moon Monastery, Taipei, Taiwan 
Kris's ideas were the shadow on lotus pond; the movement of water; when wind blow, water will move, shadow also move; and the wind blow, curtain will move, its shadow also will move on the water. So all of these, make the temple become illusion form in front the lotus pond [13].

\subsection{Xiangshan Visitor Center by Dan Norihiko, Sun Moon Lake, Taiwan}

Sun Moon Lake is the largest body of water in Taiwan as well as a tourist attraction. Located in Yuchi Township, Nantou County. The east side of the lake resembles a sun while the west side resembles a moon, hence the name. The lake and its surrounding countryside have been designated one of thirteen national scenic areas in Taiwan. The area surrounding the lake has many trails for hiking. The area draws tourists from all over the country and its unique attractions are increasingly a magnet for international visitors.

The Xiangshan Visitor Center is a visitor center overlooking Sun Moon Lake in Taiwan. The center was constructed in 2010. The center was designed by architect Dan Norihiko with a theme of promoting the harmonious integration between human habitation and the natural world.

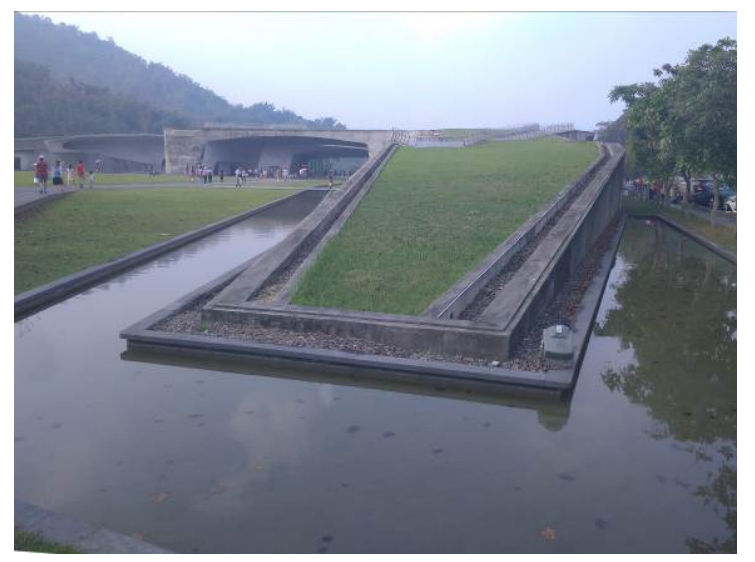

Fig. 4. Xiangshan Visitor Center and surrounding landscape, Sun Moon Lake, Taiwan

The basic policy was to present a new symbiotic example of the relationship between the architecture and its natural environment, which would refrain from destroying the surrounding landscapes, and bring out and expand the property's potential strength as much as possible. Composed of two beautifully curved buildings (Fig. 4), Xiangshan Visitor Center seems to boast very cutting edge architectural designs, but give it a second look, you will realize that it actually stands out for its greyish white architecture and fair-faced concrete surfaces. As simple and original as it can be, Xiangshan Visitor Center is dominated by a touch of Zen and in perfect harmony with the world around it. It has great views from the floor-to-ceiling windows, where beams of sunlight get to shine through. Visitors can even go up to the rooftop and have a stroll in the lush greenery, appreciating the sheer beauty of Sun Moon Lake. The structure consists of two curved wings with central canopies, the latter each measuring $34 \mathrm{~m}$ in length and $8 \mathrm{~m}$ in height [14]. 


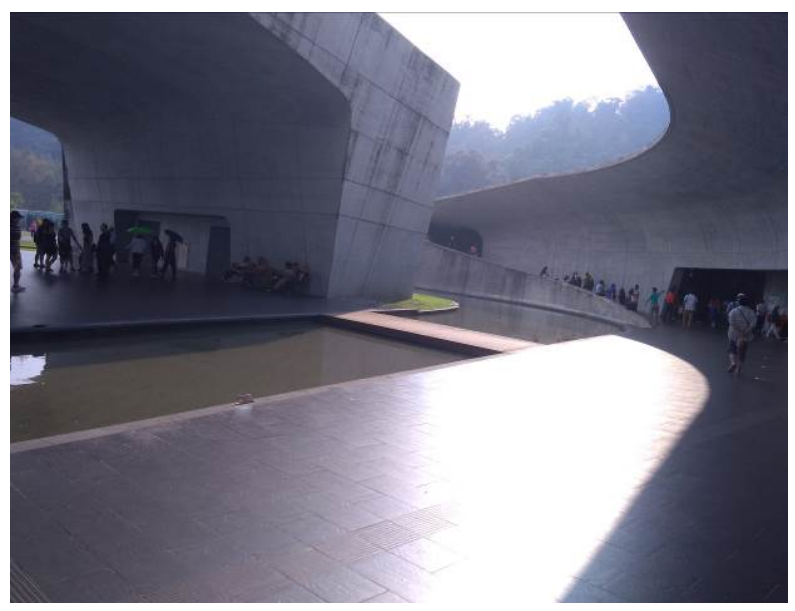

Fig. 5. Space between two beautifully curved buildings, Sun Moon Lake, Taiwan

Approach to further connect the architecture with the site, a large basin of water sits between the lake-facing windows of the center to the edge of the site. The result is a visual extension of the lake, inviting its elements directly up to the viewer. A basin of water between the building (Fig. 5.) and the lake reflects a rippling image of the surrounding trees.

\subsection{National Taichung Theater by Toyo Ito, Taichung, Taiwan}

The National Taichung Theater is a new type of construction project, utilizing 3D curved surfaces and a natural flow of space. This is a place where an abstract concept has become reality. The design uses simple horizontal and perpendicular variations to create a changed space, where hard, artificial lines have been replaced with an organically flowing and flexible system.

"I aimed to create the architecture of this opera house in such a way that the inside and outside are continuous in a like manner to how bodies are connected to nature through organs such as the mouth, nose, and ears," explained Toyo Ito [15].
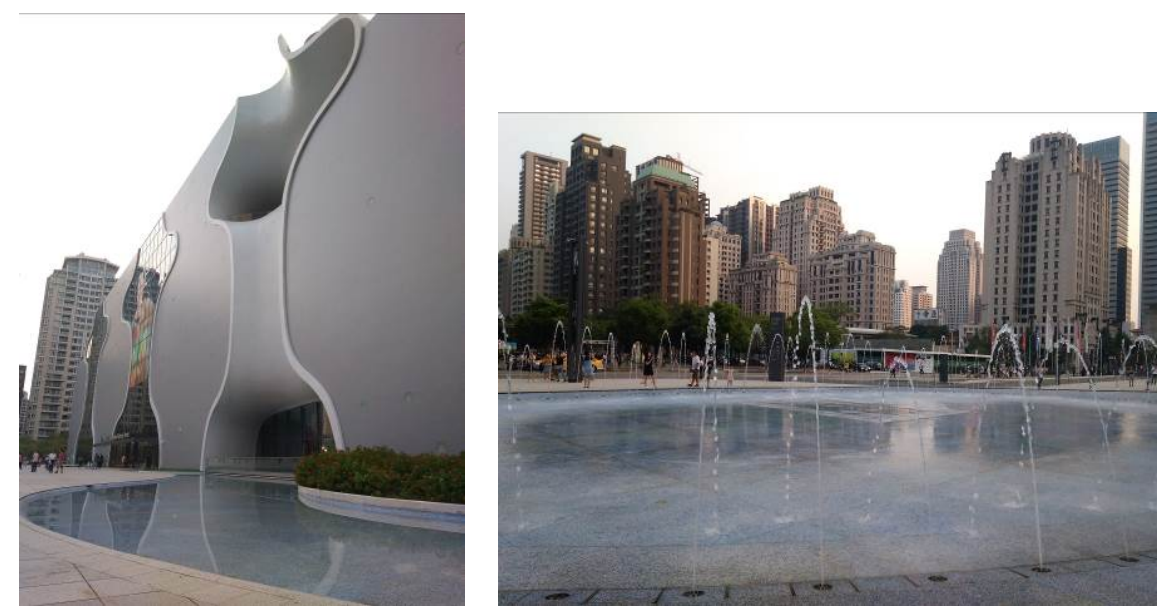

Fig. 6. Exterior water space in front National Taichung Theater 
"I am always searching for a building which is something like a ripple on a river-- one that can follow the river's currents but maintain its own spatial integrity." If we look at the world like a river, then constructing a building is generally just like plunging a wooden stake into a river. The stake enters but has no relationship to the flow (Fig. 6.).

Toyo Ito uses steel to seek the shape of freedom. Seeking to embrace humanity's warmth and an atmosphere of friendship, while breaking from Taiwan's established shapes, Ito reconstructs the flow of space. He says, "A good design allows a person to feel their own freedom within them." In this enigmatic cave space, you can be drawn in by the natural light, as well as the sounds and images of wind and water that compose this cozy environment. Every surface of this building is intertwined, flowing from this venue, to the rooftop garden, to the culture store, to the dining area, etc. In this building the water from outside coming inside and creates the river (Fig. 7.) [15].

In addition to using sustainability concepts, green construction inside and out gives rise to a natural order. This building creates a cultural life, once again creating an aesthetic that promotes a symbiotic relationship between humans and the natural world.
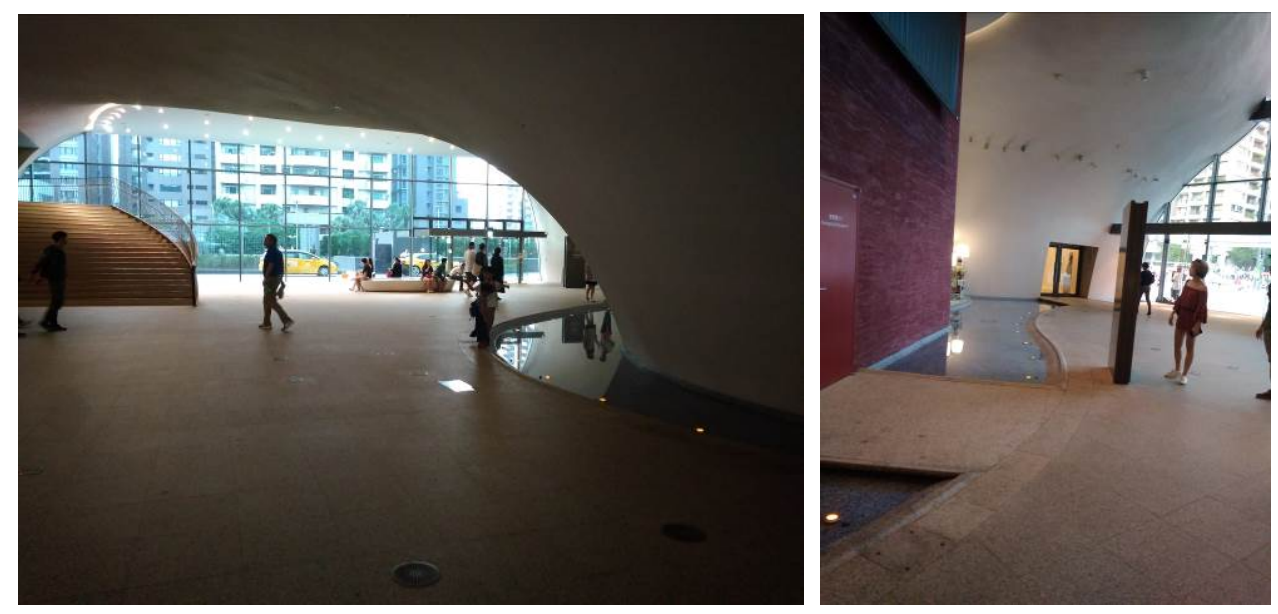

Fig. 7. Interior river, National Taichung Theater

\section{Conclusion}

James Wines in his book Green Architecture writes about the failure of architects to convert the noble objectives equivalent to artistic expression. And also that without art whole idea of sustainability falls. People will never want to maintain an aesthetically inferior building in your area, regardless of whether it is equipped with high-quality thermal glazing, photovoltaic cells and floor coverings without emissions. The aesthetic and nature value of the building becomes a precondition for its sustainability, how is showed mostly in country like is Taiwan, where water has strong roots in religion and everyday life. Three presented buildings show three different designs in the context of water. In the first case the water symbolizes a strong element of religion, in the second case the building is designed in the symbiosis of the surrounding nature and the environment, the third example, where the water appears in the form of a fountain and an indoor river, also shows the water itself and the water whirlpool were the inspiration for design and shape of a building.

This work was supported by: VEGA 1/0202/15 Bezpečné a udržatel'né hospodárenie s vodou v budovách tretieho milénia/ Sustainable and Safe Water Management in Buildings of the 3rd. Millennium. 


\section{References}

1. S. Burmila, T. D. Danielb, J. D. Hetheringtonc, Human values and perceptions of water in arid landscapes. Landscape and Urban Planning 44, 99-109 (1999)

2. S. Solomon, Water: The epic struggle for wealth, power, and civilization. New York: HarperCollins (2010)

3. D. Sedlak, Water 4.0: The Past, Present, and Future of the World's Most Vital Resource. New Haven Yale University Press (2015)

4. R. Kaplan, S. Kaplan, The Experience of Nature: A Psychological Perspective. Cambridge University Press, 9 (1989)

5. J. M. Whalley, Water in the landscape. Landscape and Urban Planning 16, 145-162 (1988)

6. S. Völker, T. Kistemann, The impact of blue space on human health and well-being Salutogenetic health effects of inland surface waters: A review. International Journal of Hygiene and Environmental Health 214, 449-460 (2011)

7. S. Völker, H. Baumeister, T. Classen, C. Hornberg, T. Kistemann, Evidence for the temperature-mitigating capacity of urban blue space- A health geographic perspective. Erdkunde, Volume 67, Issue 4, 355-371 (2013)

8. G. Manteghi, H. Bin Limit, D. Remaz, Water bodies an urban microclimate: A review. Modern Applied Science, Volume 9, Issue 6, 1-12 (2015)

9. Taiwan [online] https://en.wikipedia.org/wiki/Taiwan\#Religion

10. G. Lazenby, The Feng Shui House Book: A New Approach to Interior Design. Conran Octopus Ltd, 60 (2003)

11. R. Giblett, The Tao of Water. Landscapes: the Journal of the International Centre for Landscape and Language, Volume 3, Issue 3 (2009)

12. Water-Moon Monastery [online] http://www.klcse.com/water-moon-monastery.html

13. THEORIES OF ARCHITECTURE, Water Moon Monastery, by Kris Yao [online] http://merayjiacyfoo.wixsite.com/theories/single-post/2016/02/03/Water-MoonMonastery-by-Kris-Yao

14. Sun Moon Lake Administration Office of Tourism Bureau [online] https://www.archdaily.com/771070/sun-moon-lake-administration-office-of-tourismbureau-norihiko-dan-and-associates

15. National Taichung Theater, Design [online] http://en.npac-ntt.org/archive?uid=10 